San Jose State University

From the SelectedWorks of Fred E. Foldvary

Summer 2001

\title{
Technology and Market Failure
}

Fred E Foldvary, San Jose State University

Daniel B Klein, Santa Clara University 
Using the same free market principles, government could establish a market for community lending "vouchers" that would benefit low-income neighborhoods while rewarding efficient lenders. Bank regulators could require banks to acquire a certain amount of CRA loan vouchers each year, which would represent a certain amount of money lent to low-income neighborhoods. But all of the banks would not need to make those loans directly; some banks could make more low-income neighborhood loans than regulators require and then sell the surplus CRA vouchers to other banks that did not make as many loans. Banks that could identify relatively good inner-city loans could specialize in that business and make additional money by selling their credits to banks that wanted to get out of the market.

A market for community lending vouchers would be consistent with the growing bifurcation of the U.S. commercial bank system, marked by a small number of banks with branches across the nation as well as a number of much smaller banks specializing in local lending. Local banks are probably better able to make loans to marginal neighborhoods; evidence suggests that, because of the information externalities inherent in making such loans, substantial economies of scale exist in the low-income neighborhood credit market.

Some might object that such a division of labor between small banks and big banks would leave smaller banks less diversified than is healthy. But the securitization of such loans would be one way for them to avoid this pitfall. In fact, it is the separation of the regulatory value of CRA loans from the cash flow values that makes the market for vouchers so efficient.

\section{POLITICAL REALITIES}

The CRA voucher plan has the potential to bridge the divide between opposing sides of the CRA battle. Republican Senator Phil Gramm (R-Tex.), a Ph.D. economist who has long opposed CRA, would doubtless support such a plan as a way to alleviate the costs to banks of following the act's lending provisions.

Whether community activists, liberal politicians, and self-appointed community protectors would be as amenable to such a change is a different matter altogether. Already, regulators are wary of such a system, perceiving it as a threat to their power. Community leaders would undoubtedly be wary of a market-based CRA, much as they are wary of the market in general. The very idea of a bank getting out of its lending obligations by paying someone else to do the loans is anathema to those activists' anti-market beliefs.

But if the plan's supporters can articulate why such a scheme would do more for low-income neighborhoods in the long run than the current dictatorial approach, then the activists might look more kindly on the free market approach. What is more, the activists would likely favor dealing with smaller, community-based banks.

A revision of CRA could limit the act's cost to the banking industry while, at the same time, improve the credit environment for low-income neighborhoods. Hopefully, politically powerful groups that support CRA and dislike free markets will be willing to accept the benefits of that revision.

\title{
Technology and Market Failure
}

\author{
By Fred E. Foldvary and Daniel B. Klein \\ Santa Clara University
}

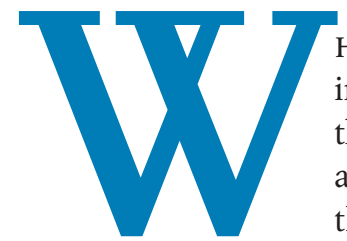

HEN GOVERNMENT INTERVENES in the marketplace, it often justifies the intervention as an effort to correct a "market failure" - an inability of the market to achieve potential gains to trade. Such inability can take many forms, but each form limits choice and efficiency.

Perhaps the most commonly described form of market failure is natural monopoly - a situation in which the nature of a product prevents alternative suppliers from emerging and competing for customers. Though consumers can obtain the product they want, the lack of competition allows the monopoly supplier to set prices well above the cost of production because the supplier possesses market power.

Another form of market failure is externality, which is exemplified by the pollution-emitting factory that imposes costs on others who use the polluted air and water. The factory is able to do that because there is no specific owner of the air or water who could demand compensation for the pollution costs.

A third form of market failure is a public good, which, for economists, is an activity that might benefit both pay-

Fred E. Foldvary is a lecturer in economics at the Leavey School of Business at Santa Clara University. He can be contacted by E-mail at ffoldvary@scu.edu.

Daniel B. Klein is an associate professor of economics at the Leavey School of Business at Santa Clara University. He is also general director of the university's Civil Society Institute. Klein can be contacted by E-mail at dklein@scu.edu.

Both authors are the editors of the forthcoming book The Half-Life of Policy Rationales: How Technology Affects Old Policy Issues. 
ing and nonpaying beneficiaries. Providers of public goods might not be compensated for the benefits they render to users and may have difficulty maintaining their paying customers. Oft-cited examples of public goods are highways and lighthouses.

Governments supposedly attempt to correct market failure through regulation, taxation, and command-andcontrol policies. But the rationales for those policies may be waning with the emergence of new technologies. We believe that technological progress is reducing the economies of scale that traditionally justified natural monopolies, and is decreasing the costs associated with creating and enforcing property rights involved in externalities and public goods. Technology can thereby reduce market failure and the rationales for government intervention.

\section{TECHNOLOGY AND NATURAL MONOPOLY}

Some of the most commonly identified forms of natural monopoly are so-called public utilities: water, sanitation, electricity, natural gas, telephone, and cable television. Each of those industries is traditionally characterized by large fixed costs and low marginal costs; it is costly to establish a new

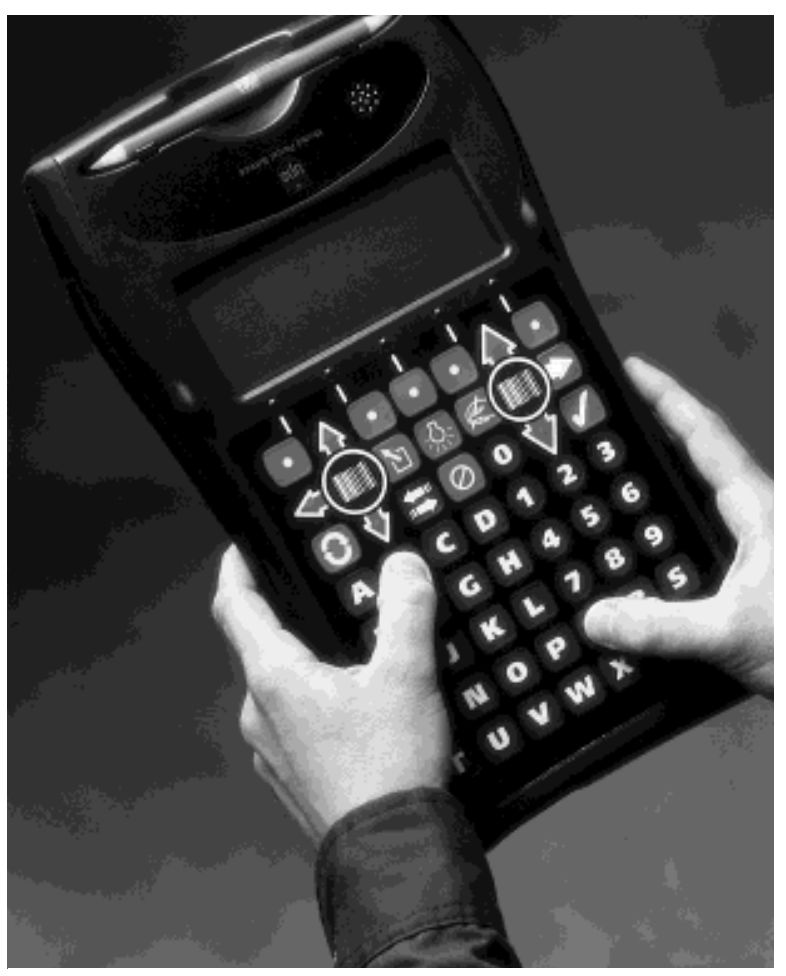

TECHNOLOGY AND THE MAIL: UPS's package-tracking diad. economies of scale for the utilities and may have discouraged potential competitors, even apart from the monopoly privileges they enjoyed.

But technological advances have given rise to competitive small-scale generators that are connected to small local distribution grids. Furthermore, recently developed computer-controlled underground drilling technologies enable the placement of new power lines without aboveground disturbances. Those developments in generation and distribution technologies make it economically feasible for small energy companies to compete with large utilities.

Water and sanitation Technological change also makes competition more viable in water and sewage service. Privately run systems can now be placed at the site of large consumers, where the systems can inventory a quantity of raw water, treat water according to a quality hierarchy specific to the customers' uses, and then recover raw water from the waste for reuse.

The systems distill an appropriate amount of water for sensitive human uses (e.g., bathing, cooking, and drinking) while using "gray water" for landscaping, cooling, firefighting, and sanitation. Likewise, the systems separate "gray" waste- telephone company but relatively inexpensive to operate it once it is established.

According to supporters of government intervention in the marketplace, industries with such cost characteristics cannot sustain competition. Potential competitors do not enter the market and bid down prices because they understand that if they did invest in a competing system, the incumbent firm could reduce prices to marginal costs in an effort to bankrupt the competitors. Given that market power, monopoly providers can charge higher-than-efficient prices, produce less-than-efficient quantities, and earn excess profits.

To prevent natural monopolies from charging more than marginal or average cost, regulators and interventionists historically have pressured government to supervise the monopoly firms and control their prices. But in many markets, new technologies now undermine the traditional cost assumptions about natural monopolies.

Electricity In previous decades, big public utilities used large central station electric generators to provide electricity to consumers through monopoly-held transmission and distribution systems. Such large, expensive systems provided water that can be reused for other purposes from "black water" (e.g., from toilets and kitchen-disposal units) that must be treated and disposed of via sewage, vacuum truck, or some other method.

The private systems offer the promise of efficiencies that are not available to large-scale utilities, and also yield economies of scope (the heat from an electricity generator could warm and distill water, for example). Because of those efficiencies, the small private systems are becoming increasingly competitive to traditional water and sanitation utilities.

Postal services The delivery of mail remains a government monopoly in the United States and many foreign countries. But postal communication now competes with technologydriven alternatives such as faxes, E-mail, and the Internet.

In the United States, several private companies are using technology to compete with the Postal Service in the delivery of express mail, while the Internet provides for electronic payments and the transmission of documents with electronic signatures. The removal of the U.S. Postal Service's monopoly protection would allow private firms to expand their coverage and promote economies of scale 
by enabling them to jointly deliver newspapers, packages, and mail.

Telecommunications Government historically has regarded local telephone companies and television cable providers as natural monopolies. That is because potential competitors would have to construct new phone lines and cable grids that would duplicate great and uneconomical fixed costs.

But fiber optic line and drilling technologies have made competition more viable than ever. Wireless telephones and satellite television transmissions provide expanding dimensions of competition. Technology is blurring the lines of telephony, cable television, and Internet service. Change is rapid, and stagnant regulations pose a serious hazard to this rapidly developing area of the marketplace.

\section{TECHNOLOGY AND RESOURCE UTILIZATION}

Externalities and public goods may lead to market failures that stem from difficulties in monitoring, controlling, and charging for resource utilization. Those difficulties might justify alternative government controls or provision using the power to tax. But new technologies enable government and future private providers to specifically assess consumers, thus reducing the incidence of market failure.

\section{Technology is limiting the situations that once produced monopolies, externalities, and public goods.} farming and ranching. rest of society. preneurs can manage oceans with the technologies of livestock herding, "fingerprinting," tagging, sonar, satellite tracking, creation of habitat, fencing, gating, and guarding. Technology has reduced the cost of private aquatic

Air pollution Controlling and monitoring the air pollution produced by American motorists used to be a transactioncost-intensive externality. That made it difficult to assess drivers for the environmental costs that they inflicted on the

But new sensor technologies have changed that. Sensors posted at the side of the road can monitor the exhaust of passing automobiles. If the sensors are coupled with electronic license plate readers, the system can identify polluting drivers and send them pollution bills. Such a polluter-pays approach directly targets the polluters, making it much more efficient than traditional command-andcontrol methods of pollution reduction that increase costs for a large number of people and industries through smogcheck programs, alternative-fuel requirements, electric vehicles, and mandated monitoring systems in cars.

Highways and parking Traditionally, highways have been publicly provided without explicit user charges. Toll-collection entailed significant transaction costs such as delays and inconvenience for motorists, motorists' and tollbooth attendants' handling of cumbersome cash, and costly or unsightly tollbooths.

But technological change has reduced the transaction costs of toll collection. Electronic tolling allows highway users to pay tolls as easily as they pay a monthly phone bill, weakening the case for operating "freeways" and strengthening the case for roadway privatization.

Technological change has also reduced the costs of charging for street parking. Modern parking meters no longer require motorists to pay hard currency for fixed periods of time; instead, new in-vehicle meters with LCD displays can charge only for the time a car is parked in a space, and can direct payment to the appropriate owner of the space. Anyone with curb space to rent could do so without even erecting parking meters. One could well imagine turning on-street parking space over to private entrepreneurs or adjoining landowners, to rent by the minute using high-tech meters.

\section{CONCLUSION}

Technological advances are reducing transaction costs and the economies of scale that produce natural monopolies and, thus, the incidence of market failure. That, in turn, enables free markets to operate more effectively. Although there may be some countervailing effects, we feel that, on the whole, technological change is weakening the case for government intervention.
Marine resources New technologies are enhancing the ability to define, secure, trade, and enforce private property in marine resources. Just as ranchers and cattlemen in the American West secured their property with such innovations as branding and barbed wire, today entre- 